\title{
Design of Web-based Information System Sales
}

\author{
D S Soegoto ${ }^{1}$, Rismaya $^{2}$ \\ \{dedi@unikom.ac.id ${ }^{1}$, rismaya3@ mahasiswa.unikom.ac.id ${ }^{2}$ \}
}

Departemen Manajemen, Universitas Komputer Indonesia, Indonesia ${ }^{1}$,

Fakultas Teknik dan Ilmu Komputer, Universitas Komputer Indonesia, Indonesia ${ }^{2}$

\begin{abstract}
The purpose of this study is to make it easier for consumers to make buying and selling transactions and also make it easier for sellers to promote various products that can be reached by consumers without having to visit the store. In this study, descriptive analysis method is used by conducting direct interviews with PD. XYZ store as a case study. The results of this study indicate that the design of website sales can increase buying and selling transactions in stores. To increase the attractiveness of buyers, media campaigns are needed in addition to conventional promotions. The conclusion obtained in this study is that the design of sales information systems can help sellers in promoting products to increase revenue from the store and make it easier for customers to make online sales transactions. Besides that, it can also provide information about the product as a promotional event in detail and can bring prospective customers either directly to the store or chat directly through the chat feature with customers to be able to communicate easily. Making this website can create a professional impression because in terms of branding, it has its own characteristics and makes it easy for customers to make online sales transactions.
\end{abstract}

Keywords: Selling Transactions, Web, Design.

\section{Introduction}

Business process technologies such as implementation, enterprise resource planning or ERP (Enterprise Resource Planning) are the latest business technology innovations to manage and organize company processes at the product line level [1]. According to Midjan, the Sales Information System has an important role in the company. It can help managers and owners such as helping management in making decisions, can monitor product achievements, markets, employees, and sales [2].

Online marketing information systems can be used as sales transaction documents, promoting goods, and for customer ordering products [3]. Marketing information is important especially because the economy continues to emphasize service as a primary source of value. Services depend heavily on information because information quickly becomes a service in itself [4]. This process of professionalizing website development started with phrases like "make web pages dynamic" and later into "separate content from presentation" [5]. Web applications are nowadays applied and used, and their scalability for organizations is vast [6].

Many companies rely on a web application to conduct traditional business strategies and analytical data collection techniques for promotional effectiveness [7]. According to the 
research results of Lukman Gozali et all, the study can help the administration in managing the sale of books and the making of reports. In addition, this information system can also easily produce reports on information regarding book sales per month or per year accurately and precisely as expected [8]. While according to Sriyanto, Hartini et al, the usage of an e-commerce program to create a program that is engaged in buying and selling "used motorbikes" was done as a medium to introduce the products and companies described [9]. According to Niswonger in his journal, the Sales Information System as a sales statement statement in addition to the sales information system, activities will be explained through procedures that include the sequence of activities from receipt of orders from the buyer, checking for items that exist or not and forwarded by making invoices and registering applicable sales[10]. According to Reni Hartanti \& Zahra Lukita in his journal, the sales information system is very necessary for technical service to a cooperative that plays a very important role because the information system will run well and smoothly if the data processing system for the performance process supports other than that. In the current era of globalization, competition between cooperatives has occurred so tightly [11]. According to Himawan in his research, the existence of ecommerce websites that use the internet as a marketing medium makes it easier for shop owners to provide services to consumers, provides 24-hour information that can be accessed anytime and anywhere, and is designed to increase income because income is not only from stores, but also through online marketing [12].

The web serves as an integral part of daily operations that are widely used by various companies and in business matters, often rely on the web to attract clients, communicate with suppliers, and generate income [13]. The online trading system facilitates online trading through public networks using web applications that can be used by all internet users [14]. Online transactions are transactions conducted by sellers and online buyers through internet media; there is no direct meeting between buyers and sellers [15]. One way to sell is to use web-based sales which, due to that can increase the number of profits for the company [16].

The strength of this research is for the PD store. XYZ is very beneficial because it can increase visibility compared to other shops because it is better known in the internet world. Besides that, it can also provide information about products as a promotional event in detail and can bring new prospective customers either directly to the store or by chatting directly through the chat feature with customers to be able to communicate easily. Making this website can create a professional impression because, in terms of branding, it has its own characteristics. There is also a direct booking feature with the store, in contrast to promotional websites that generally only display or advertise products. In addition to the advantages of the features of advertising, promotion, ordering and the like on this website, there is also a blog feature, where website visitors can enjoy updated articles about the latest household furniture. It can be ascertained that the need for the existence of an information system is very helpful for management in making decisions and improving the buying and selling services needed. The purpose of this research is to identify whether the establishment of an online sales system can highly increase sales revenue and as a promotional media for store PD. XYZ.

In the purpose of this study, the purpose of this study is to identify whether the establishment of an online sales system can highly increase sales revenues and as a promotional medium for PD stores XYZ. Research of this paper uses a descriptive analysis method by conducting direct interviews with $\mathrm{PD}$, using descriptive analysis method by conducting interviews directly with PD stores XYZ as a case study in this study. Results of interviews with PD stores XYZ among others are that it requires promotions and media advertising, but in addition to being a medium 
for promotion and advertising, interested parties want to be able to add booking features directly to PD stores XYZ so that sales revenue increase every day.

\section{Methods}

The system research method used is a descriptive analysis method by conducting interviews directly with the store PD. XYZ as a case study in this study. As for some of the reasons this method is used, among them are that they are easy to understand and use. After finding the problem, collecting materials in the system design is done. System design is very useful for development because it can determine the final output of the built system.

\section{Results and Discussion}

This section presents several simulation results, i.e. power from the input side, inverter output side, power from the load side, efficiency, and THD. Each simulation has different parameters, so in this case, we will display one by one the parameters used.

\subsection{Selected Switching Control Signal for Analysis.}

The parameters used in the simulation of filters and transformer are shown in Tables. The first simulation results presented in this section are the effectiveness of inverters and multilevel inverters using PWL, PWM and SPWM switching control signals.

\subsection{Parameter of The Simulation.}

PD. XYZ is one of the centers of home appliances that has stood for 41 years, is well-known as a center for selling household appliances that has provided a variety of household appliances/ equipment from various brands to meet consumer needs at competitive prices and quality goods because customer satisfaction is a priority. The author conducted an interview at the PD shop XYZ located at Jln. Kalipah Apo No. 17C on Wednesday, October 3, 2018, at 4:00 p.m.

There are problems that occur in PD. XYZ. One of them is in the process of ordering / buying and selling goods with customers that can be done by telephone or by coming directly to the store, but it is not enough just to do the direct selling process in the store because they want to attract more customers who often use the internet for the sale process goods. Therefore, to utilize highly sophisticated technology, store PD. XYZ wants to build a web-based sales application that aims to attract more customers who can do business transactions through ordering on the website while promoting store PD. XYZ to internet users.

Below are the website design images that will be used. The first page can be seen in (Figure 1). 


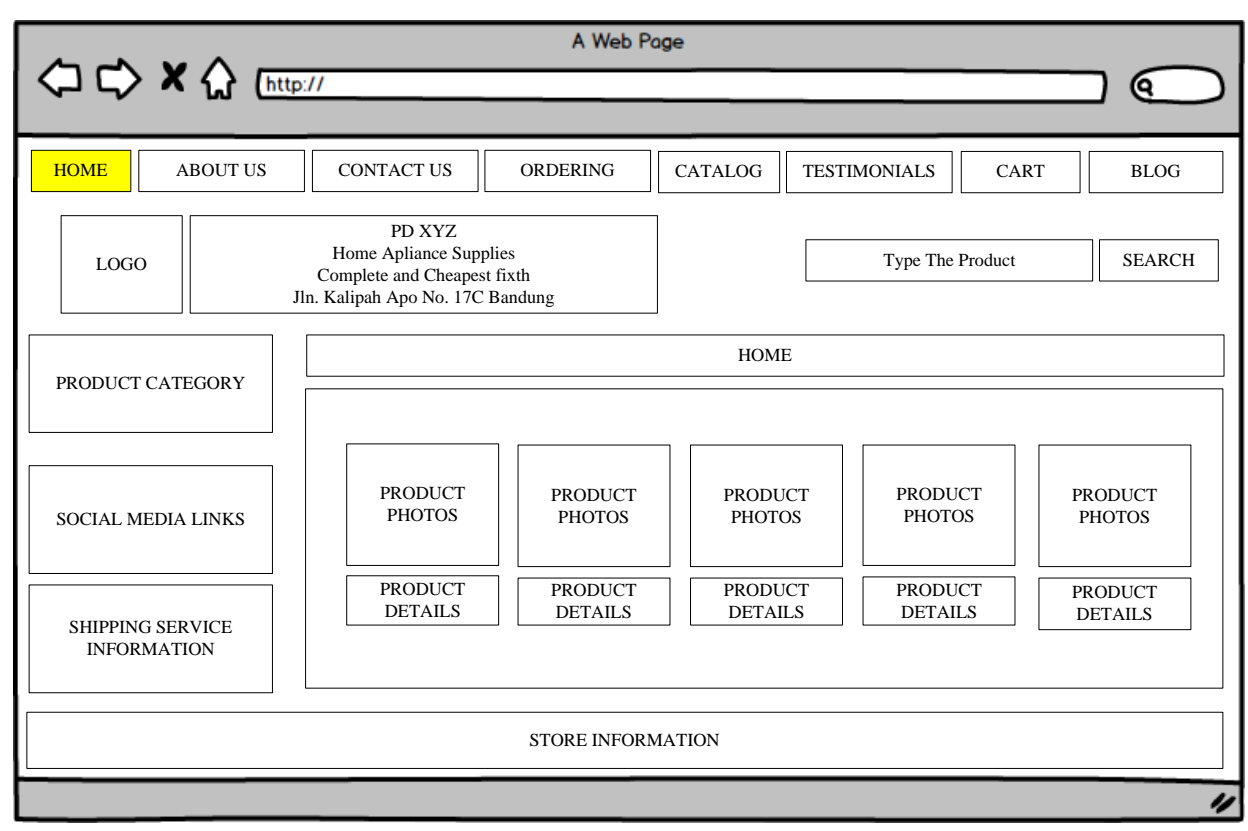

Fig 1. Home.

On the Home page, it displays some of the latest products in the store PD. XYZ. There is some information on product categories, social media links, and information about the store PD. XYZ. The next page has a menu of about us (Figure 2).

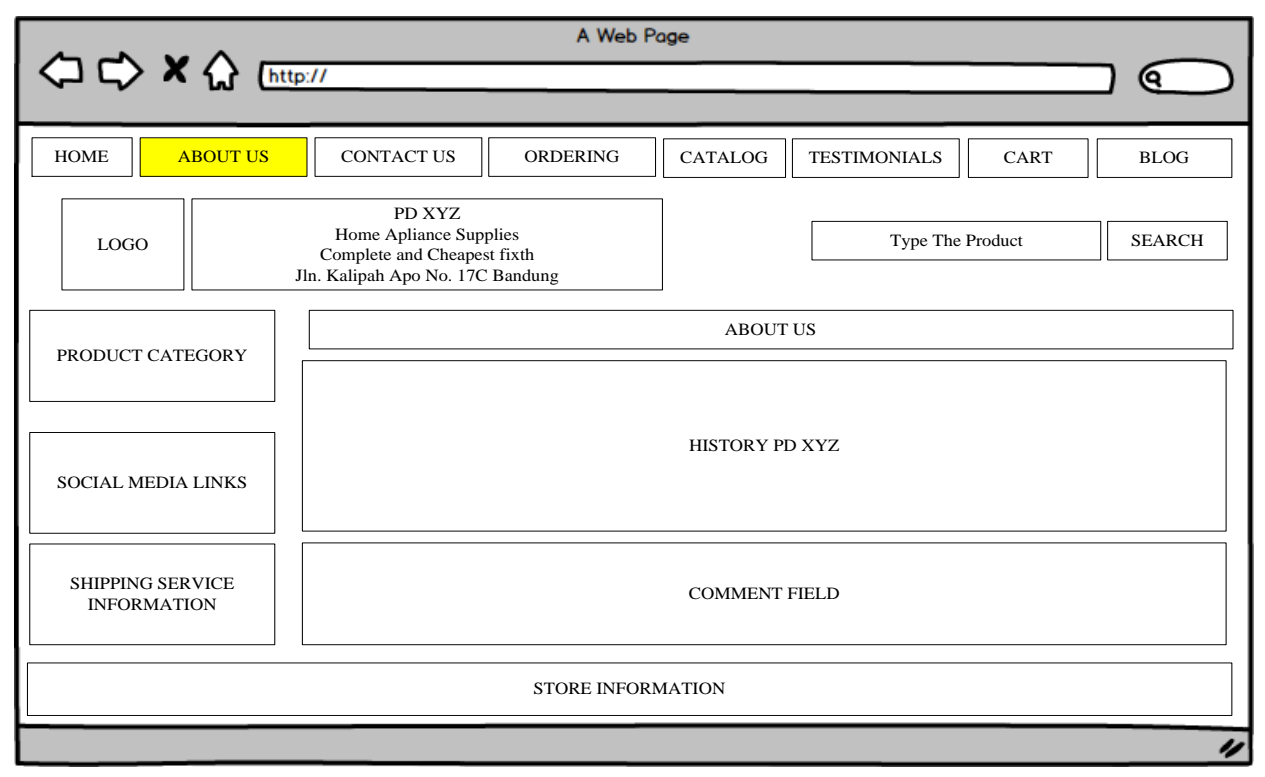

Fig 2. About Us. 
On this page, customers can find out the history of the PD. XYZ store and can find out where the store is located. The next page is the contact us menu (Figure 3).

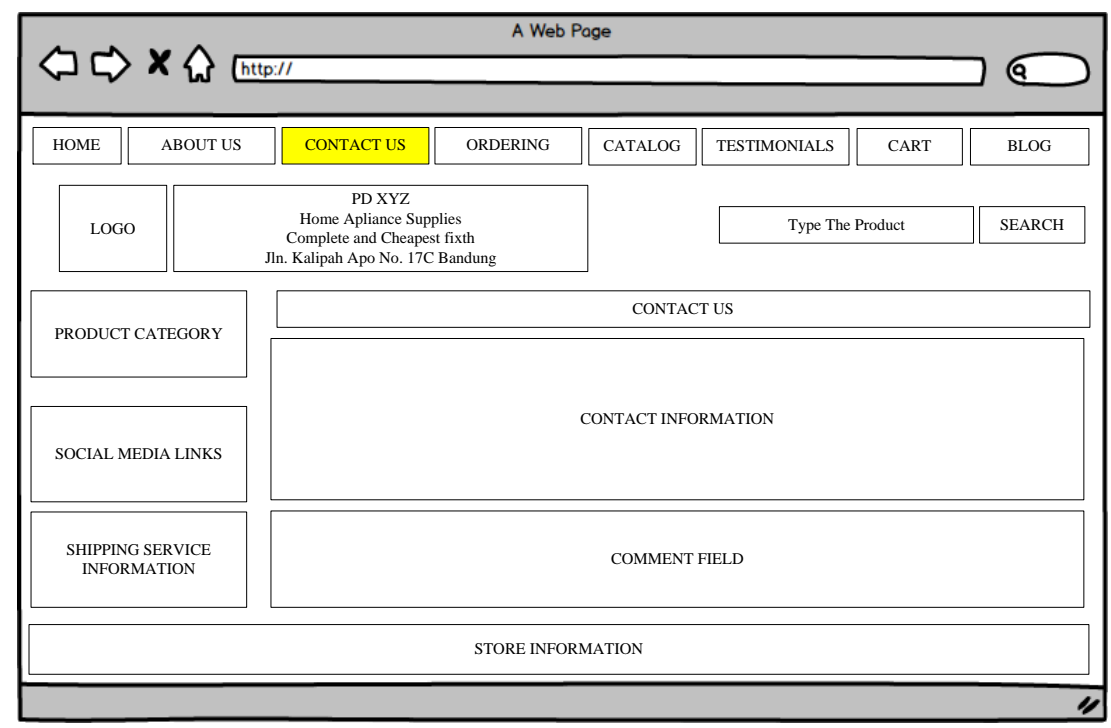

Fig 3. Contact Us

On this page, customers can find out the contact information that can be used to contact the PD. XYZ store. The next page is the Order sub menu (Figure 4).

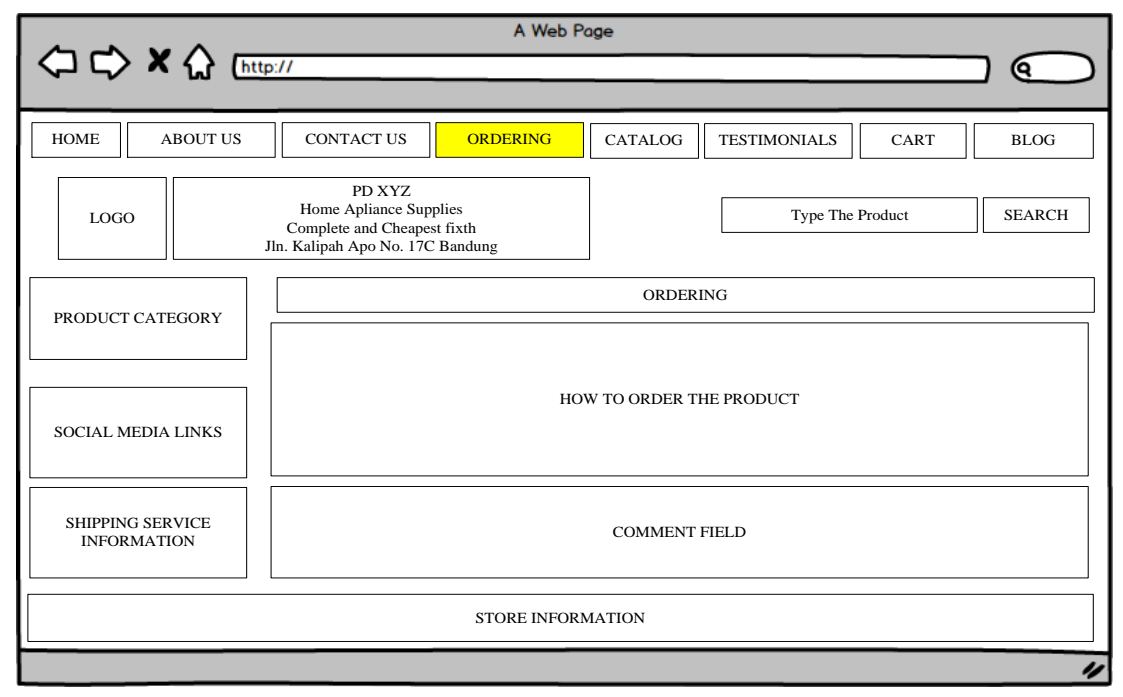

Fig 4. Ordering. 
On this page, customers can find out how to order online and what order procedures that the customers must do. The next page is the catalog menu (Figure 5).

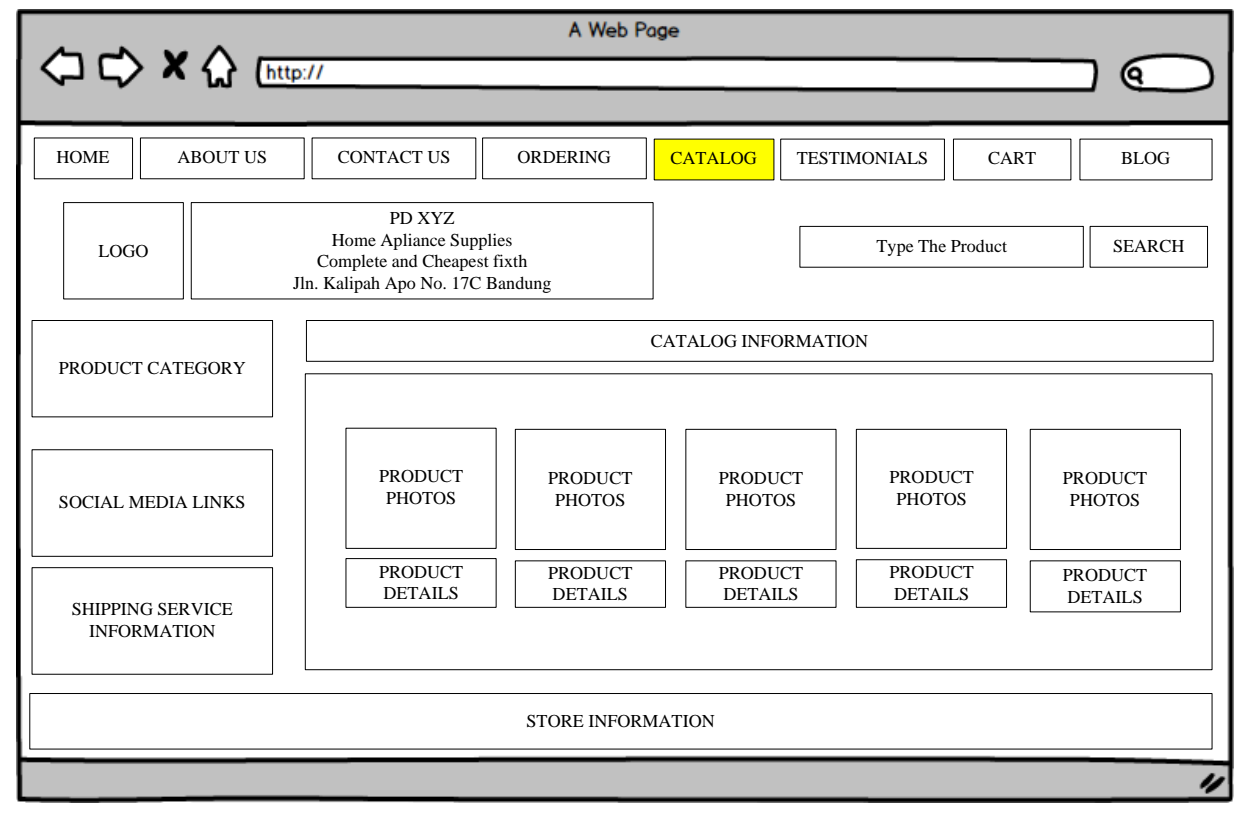

Fig 5. Catalog.

On this page, it displays all products available at the PD. XYZ store. Here, the customer can find out the product in detail. The next page is the testimonial menu (Figure 6).

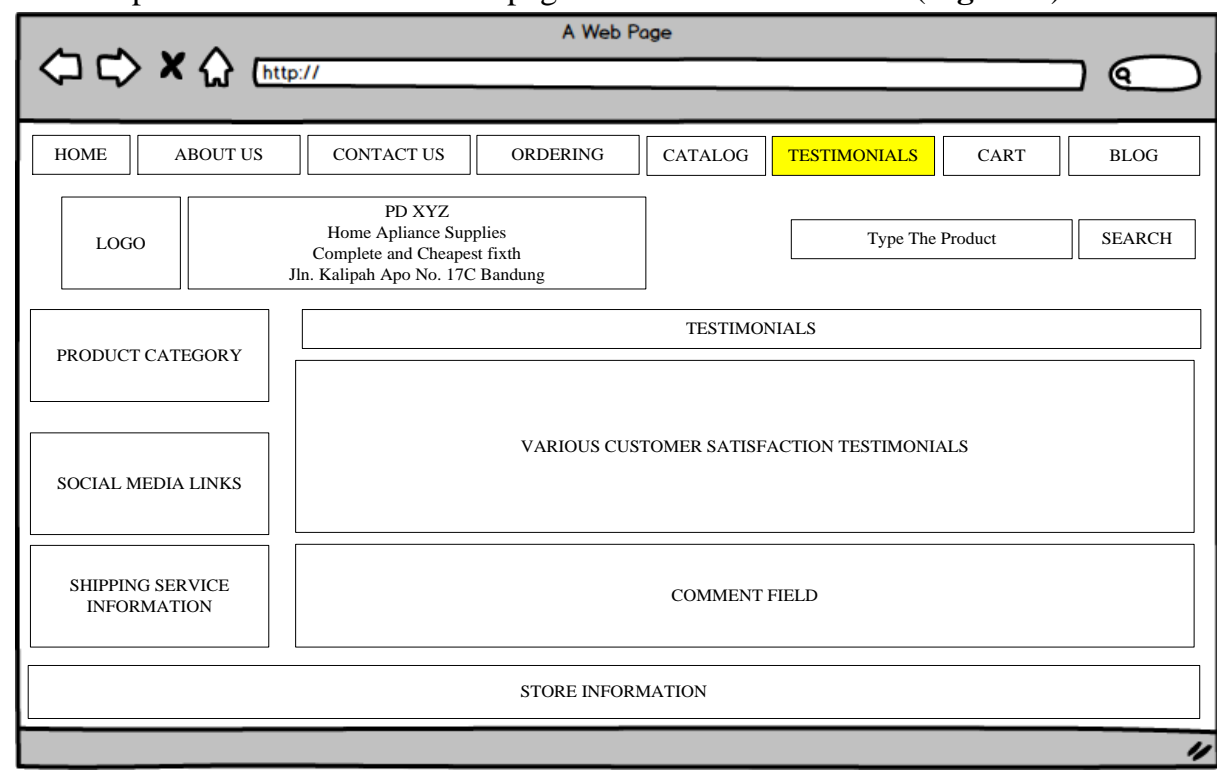

Figure 6. Testimonials. 
On this page, Customers can see the feedback from customers regarding their satisfaction of the service from PD. XYZ store. The next page is the ordering cart menu (Figure 7).

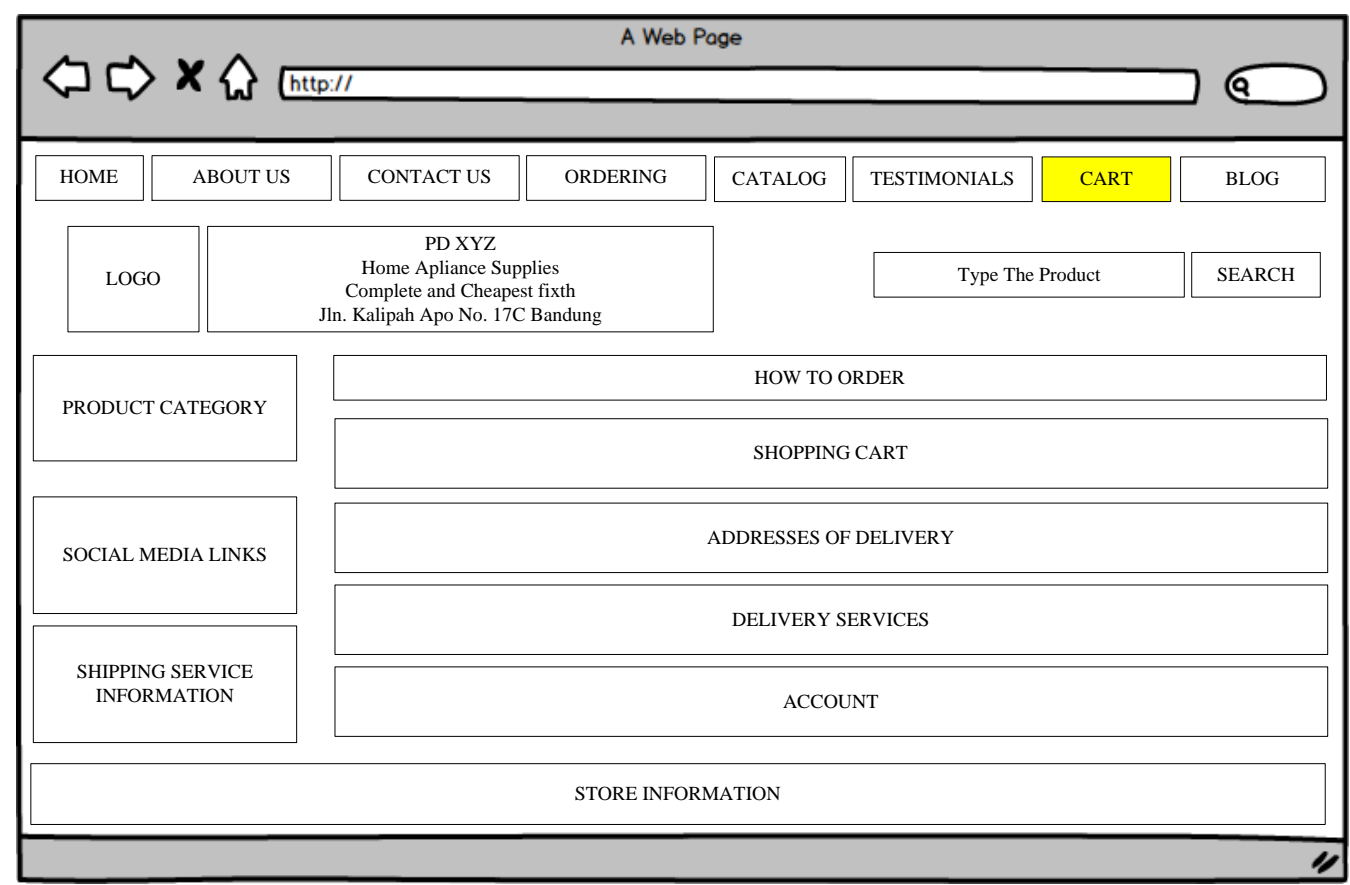

Fig 7. Cart.

On this page, customers can order items to be purchased that have provisions such as filling in the shopping cart / product items to be purchased, shipping addresses, shipping services, and accounts for payment methods. If you have taken these steps, the store will validate if the money has been entered by uploading proof of payment, then the process of shipping the goods will be made on the form that has been filled in by the customer. The next page is the blog menu (Figure 8). 


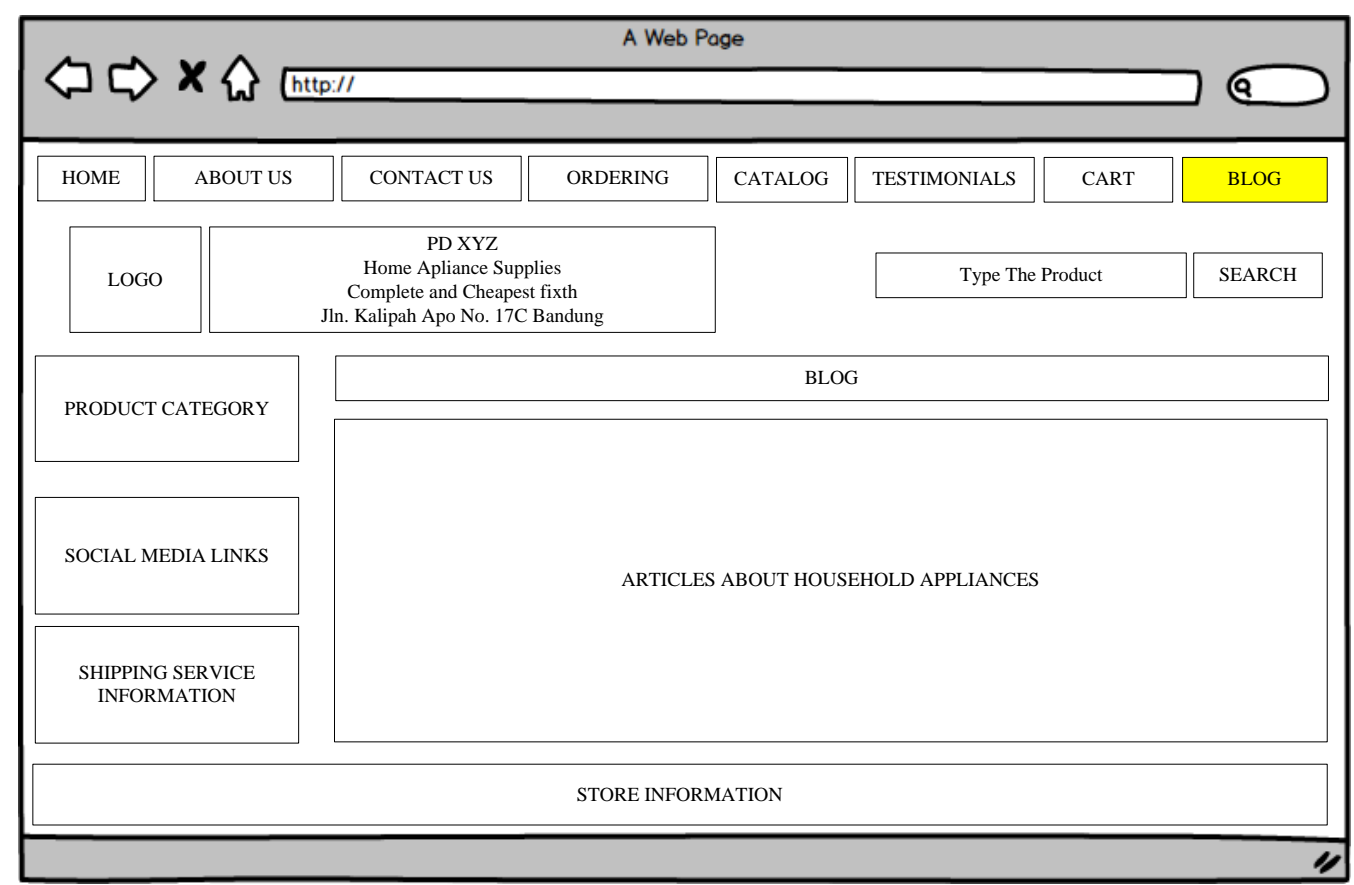

Fig 8. Blog Articles.

On this page, customers can enjoy interesting articles about today's household appliances.

\section{Conclusion}

With web design for media promotion and sales, PD stores XYZ will be assisted in terms of marketing various types of products online and making it easier for customers to make online sales transactions. In addition to increasing the attractiveness of buyers, media campaigns are needed to conventional promotions. Besides that, sales information systems can help sellers promote products in an effort to increase revenue from the store and makes it easier for customers to make online sales transactions. It can also provide information about the product as a promotional event in detail and can bring prospective customers either directly to the store or by chatting directly through the chat feature with customers making them able to communicate with the business easily. Making this website can create a professional impression because in terms of branding, it has owned its characteristics and makes it easy for customers to make online sales transactions.

\section{References}

[1] Soegoto, Eddy Soeryanto.: Entrepreneurship Menjadi Pebisnis Ulung. Jakarta : PT Elex Media Komputindo Kompas Gramedia. (2014).

[2] Susianawati, H., Tjandrarini, A. B., \& Wulandari, S. H. E.: Design of Web-Based Sales Information System at CV Gemilang Indonesia. Jurnal JSIKA, 6(1), 29-35. (2017). 
[3] Fitriana, R., Kurniawan, W., Barlianto, A., \& Putra, R. A.: Marketing information system online design for craftsmen small medium enterprises (case study: craftsmen ac). In IOP Conference Series: Materials Science and Engineering (Vol. 114, No. 1, p. 012084). IOP Publishing. (2016).

[4] Abeka, S. O.: User satisfaction and acceptance of web based marketing information system among microfinance institutions in Nairobi region, Kenya. International Journal of Academic Research in Business and Social Sciences, 2(9), 368. (2012).

[5] Van Capelleveen, G., Amrit, C., \& Yazan, D. M.: A literature survey of information systems facilitating the identification of industrial symbiosis. In From Science to Society(pp. 155-169). Springer, Cham. (2018).

[6] Haddad Nosrati, N., \& Riisalo, T.: The design and development of a web application to improve business processes and performance in an innovative media company-a case study of JS Suomi Ltd. (2017).

[7] N.-C. Yang and M.-D. Le, Optimal design of passive power filters based on multiobjective bat algorithm and pareto front, Applied Soft Computing, vol. 35, pp. 257266, (2015).

[8] M. Buyuk, A. Tan, M. Tumay, and K. C. Bayindir,: Topologies, generalized designs, passive and active damping methods of switching ripple filters for voltage source inverter: A comprehensive review, Renewable and Sustainable Energy Reviews, vol. 62, pp. 46 69, (2016).

[9] Aryanto, A., \& Tjendrowaseno, T. I.: Pembangunan Sistem Penjualan Online Pada Toko Indah Jaya Furniture Surakarta. Speed-Sentra Penelitian Engineering dan Edukasi, 4(4). (2013).

[10] Haryanti, S. S.: Rancang Bangun Sistem Informasi E-Commerce Untuk Usaha Fashion Studi Kasus Omah Mode Kudus. Speed-Sentra Penelitian Engineering dan Edukasi, 3(1). (2011).

[11] Nugraha, A., \& Octasia, A.: Sistem Informasi Penjualan Kaos Berbasis Web Pada Distro Sickness Berbasis E-Commerce. In Seminar Nasional Ilmu Pengetahuan dan Teknologi Komputer (pp. 299-INF). (2016).

[12] Himawan, H., Saefullah, A., \& Santoso, S.: Analisa dan Perancangan Sistem Informasi Penjualan Online (E-Commerce) pada CV Selaras Batik Menggunakan Analisis Deskriptif. Scientific Journal of Informatics, 1(1), 53-63. (2014).

[13] Fitri, R. S., Rukun, K., \& Dwiyani, N.: Perancangan dan Implementasi Sistem Informasi Penjualan Komputer dan Accessories Pada Toko Mujahidah Computer Berbasis Web. Jurnal Vokasional Teknik Elektronika dan Informatika, 4(1). (2018).

[14] Santoso, S., Kauffman, R. J., \& Aristo, N. C.: The Information System of Name Card Sales Based on Digital Marketing to Improve Creativepreneur on College E-Commerce Website. Aptisi Transactions on Technopreneurship, 1(1), 71-81. (2019).

[15] Abadi, S., Huda, M., Hehsan, A., Mohamad, A. M., Basiron, B., Ihwani, S. S., ... \& Noor, S. S. M.: Design of online transaction model on traditional industry in order to increase turnover and benefits. International Journal of Engineering and Technology, 7(2.27), 231-237. (2018).

[16] Soegoto, D. S., \& Cica, C.: Design of Web-based Sales Information System on Fashion Shop in Bandung, Indonesia. In IOP Conference Series: Materials Science and Engineering (Vol. 407, No. 1, p. 012023). IOP Publishing. (2018). 